\title{
Sintesis Nanokristal Perak Menggunakan Ekstrak Kulit Buah Manggis (Garcinia mangostana L.)
}

\author{
Winda Rahayu Okta Yanti*, Astuti \\ Laboratorium Fisika Material, Jurusan Fisika \\ Fakultas Matematika dan Ilmu Pengetahuan Alam Universitas Andalas \\ Kampus UNAND Limau Manis, Padang 25163, Indonesia \\ *windaroyw4al@gmail.com
}

\begin{abstract}
ABSTRAK
Sintesis nanokristal perak telah berhasil dilakukan menggunakan ekstrak kulit buah manggis (Garcinia mangostana L.). Proses sintesis dilakukan dengan mencampurkan larutan $\mathrm{AgNO}_{3} 1 \mathrm{mM}$ dengan $2,5 \mathrm{~mL}$ ekstrak kulit buah manggis dan ditambahkan dengan 12 mL PEG 3\%. Larutan $\mathrm{AgNO}_{3}$ yang digunakan memiliki variasi 35, 40, 45, 50, dan $60 \mathrm{~mL}$, diaduk dengan menggunakan magnetic stirrer selama 3 jam kemudian dilakukan sintering dengan suhu $500^{\circ} \mathrm{C}$ selama 1 jam. Sampel dikarakterisasi menggunakan XRD (X-Ray Diffraction), SEM (Scanning Electron Microscope), dan FTIR (Fourier Transform Infrared). Berdasarkan hasil XRD, nanopartikel perak yang dihasilkan memiliki ukuran kristal berkisar antara 32,29 nm - 126,55 nm dengan struktur kristal kubik FCC (Face Centre Cubic). Selai itu, terdapat kecenderungan bahwa semakin kecil volume $\mathrm{AgNO}_{3}$ yang digunakan, ukuran nanokristal perak yang dihasilkan juga akan semakin kecil. Berdasarkan hasil SEM , nanopartikel perak yang dihasilkan masih terdapat gumpalan. Kondisi optimum dengan ukuran kristal paling kecil didapat pada jumlah $\mathrm{AgNO}_{3} 35$ mL dengan ukuran kristal 32,2908 nm.

Kata kunci: ekstrak kulit manggis, $\mathrm{AgNO}_{3}$, PEG 6000, nanokristal perak
\end{abstract}

\section{ABSTRACT}

Synthesis of silver nanocrystals was successfully carried out using mangosteen peel extract (Garcinia mangostana L.). The synthesis process was carried out by mixing $1 \mathrm{mM} \mathrm{AgNO}$ solution with 2,5 $\mathrm{mL}$ mangosteen peel extract and added with $12 \mathrm{~mL} \mathrm{PEG} \mathrm{3 \%}$ and using variations of $\mathrm{AgNO}_{3}$ 60, 50, 45, 40, and $35 \mathrm{~mL}$, stirred by using a magnetic stirrer for 3 hours then sintering at $500^{\circ} \mathrm{C}$ for 1 hour. The samples were characterized using XRD (X-Ray Diffraction), SEM (Scanning Electron Microscope), and FTIR (Fourier Transform Infrared). Based on the XRD results, silver nanoparticles have a crystal size between $32.29 \mathrm{~nm}$ to $126.55 \mathrm{~nm}$ with the Face Center Cubic (FCC) cubic crystalline structure. Based on the results of SEM, silver nanoparticles still have aglomerate. The optimum conditions with the smallest crystal size were obtained on the variation $\mathrm{AgNO}_{3} 35 \mathrm{~mL}$ with a crystal size of $32.2908 \mathrm{~nm}$.

Keywords: Mangosteen peel extract, $\mathrm{AgNO}_{3}, \mathrm{PEG} 6000$, silver nanocrystals

\section{PENDAHULUAN}

Nanopartikel adalah material yang memiliki ukuran diameter antara 1-100 nm dan memiliki sifat-sifat yang lebih unggul dibandingkan dengan material yang berukuran besar (bulk). Salah satu nanopartikel yang banyak diaplikasikan pada saat ini adalah nanopartikel perak. Aplikasi dari nanopartikel perak diantaranya sebagai diagnosa molekuler dan alat fotonik, sebagai bahan pelapis antimikroba, beberapa tekstil, keyboard, perban, dan perangkat medis (Abdullah, 2009).

Sintesis nanopartikel perak dapat dilakukan dengan menggunakan metode fisika dan metode kimia. Akan tetapi, metode tersebut dapat menimbulkan dampak negatif, seperti penggunaan pelarut beracun, konsumsi energi yang tinggi, dan mengeluarkan limbah berbahaya (Gopinath dkk., 2012). Oleh sebab itu, perlu dikembangkan sebuah metode yang ramah lingkungan, sehingga muncullah sebuah metode dengan menggunakan bahan alami, yaitu ekstrak tanaman. Pada metode ini, sintesis nanopartikel dilakukan dengan memanfaatkan senyawa-senyawa organik yang terkandung didalam tanaman untuk mereduksi ion logam. Tanaman manggis diketahui mengandung senyawa mangostin yang merupakan senyawa turunan xanton. Senyawa mangostin ini memiliki gugus hidroksil $(-\mathrm{OH})$ yang dapat berperan dalam proses reduksi ion $\mathrm{Ag}+$ menjadi $\mathrm{Ag}$ nanopartikel.

Beberapa penelitian yang telah dilakukan sebelumnya untuk sintesis nanopartikel perak melibatkan agen pereduksi berupa bagian tanaman yang masih diperlukan oleh tanaman tersebut. Penelitian yang dilakukan oleh Massake dkk. (2014) menggunakan daun manggis 
sebagai agen pereduksi yang masih diperlukan oleh tanaman manggis dalam proses fotosintesis. Penggunaan bagian tanaman yang masih diperlukan oleh tanaman tersebut dapat menghambat pertumbuhan pada tanaman. Selain itu, hasil yang diperoleh menunjukkan ukuran partikel lebih besar dari $100 \mathrm{~nm}$, yaitu berkisar antara 204,23-562,49 nm dan diameter rata-rata 339,44 nm. Ukuran nanopartikel perak dapat dikontrol dengan penambahan polimer dan surfaktan. Astuti dkk. (2013) telah berhasil menurunkan ukuran nanopartikel $\mathrm{Fe}_{3} \mathrm{O}_{4}$ menggunakan surfaktan Polietilen Glikol 4000 (PEG 4000).

Penelitian lainnya dilakukan oleh Junaidi dkk. (2015) menggunakan bahan kimia dalam proses sintesis nanopartikel perak. Penggunaan bahan kimia dalam sintesis nanopartikel perak akan menimbulkan banyak dampak negatif. Pada penelitian ini, digunakan polietilen glikol (PEG) dengan massa molekul 6000 untuk mengontrol ukuran partikel, sehingga nanopartikel yang dihasilkan memiliki ukuran kurang ari $100 \mathrm{~nm}$, yaitu berkisar antara 12,01-30,77 nm.

Pada penelitian ini, dilakukan sintesis nanopartikel perak menggunakan ekstrak kulit buah manggis (Garcinia mangostana L.) dengan menggunakan metode reduksi. Metode reduksi dipilih dalam proses sintesis nanopartikel perak dikarenakan metode ini paling efektif dibandingkan metode yang lainnya. Hal ini dikarenakan langkah kerja yang mudah, cepat, murah, dan menggunakan temperatur rendah. Agar tidak terjadi aglomerasi pada partikel perak, maka digunakan PEG 6000. Disamping itu, PEG 6000 juga dapat digunakan untuk mengontrol pertumbuhan kristal (Astuti, dkk. 2013). PEG 6000 memiliki sifat yang stabil, mudah bercampur dengan komponen lain, tidak beracun, dan tidak iritatif. Sintesis nanopartikel perak dengan menggunakan metode reduksi melibatkan senyawa lain, pada penelitian ini digunakan perak nitrat $\left(\mathrm{AgNO}_{3}\right)$. Perak nitrat $\left(\mathrm{AgNO}_{3}\right)$ merupakan senyawa organik yang bisa menjadi prekursor serbaguna untuk banyak senyawa perak lainnya. Hal ini disebabkan karena senyawa ini relatif stabil terhadap cahaya, sehingga bisa larut dalam banyak pelarut, termasuk air. Penggunaan kulit buah manggis (Garcinia mangostana L.) dalam sintesis nanokristal perak dapat mencegah timbulnya dampak negatif dari penggunaan pelarut beracun dalam proses sintesis nanokristal perak.

\section{METODE}

Sampel yang digunakan berupa kulit buah manggis yang masih segar. Kulit buah manggis dipotong-potong dan ditimbang sebanyak 40 gram, kemudian dimasukkan ke dalam gelas kimia $500 \mathrm{~mL}$ dan ditambahkan $50 \mathrm{~mL}$ akuabides lalu dipanaskan sampai mendidih (mencapai suhu $100^{\circ} \mathrm{C}$ ). Setelah mendidih, air rebusan kulit buah manggis dibiarkan hingga mencapai suhu ruang. Kemudian disaring menggunakan kertas saring Whatman no.42. Sampel yang telah disaring kemudian disimpan di dalam lemari es untuk pemakaian selanjutnya.

Larutan $\mathrm{AgNO}_{3}$ sebanyak 35, 40, 45, 50, dan $60 \mathrm{~mL}$ dimasukkan ke dalam gelas ukur $100 \mathrm{~mL}$, lalu ditambahkan $12 \mathrm{~mL}$ PEG 3\% dan dicampurkan dengan air rebusan kulit buah manggis $2,5 \mathrm{~mL}$, kemudian didiamkan selama 155 menit. Setelah itu, larutan diaduk dengan menggunakan magnetic stirrer selama 3 jam sampai mengental lalu disinterring selama 1 jam pada suhu $500^{\circ} \mathrm{C}$, sehingga sampel berbentuk serbuk. Sampel yang berbentuk serbuk kemudian dikarakterisasi menggunakan XRD, SEM, dan FTIR.

\section{HASIL DAN DISKUSI}

\subsection{Struktur dan Ukuran Kristal}

Pengujian sampel dengan menggunakan XRD dilakukan untuk mengetahui struktur dan ukuran kristal dari masing-masing sampel. Sampel 1 adalah sampel dengan variasi $\mathrm{AgNO}_{3} 60$ mL, sampel 2 menggunakan variasi $\mathrm{AgNO}_{3} 50 \mathrm{~mL}$, sampel 3 dengan variasi $\mathrm{AgNO}_{3} 45 \mathrm{~mL}$, sampel 4 dengan variasi $\mathrm{AgNO}_{3} 40 \mathrm{~mL}$, dan sampel 5 dengan variasi $\mathrm{AgNO}_{3} 35 \mathrm{~mL}$.

Pola difraksi untuk masing-masing sampel ditunjukkan pada Gambar 1. Berdasarkan Gambar 1 terlihat bahwa puncak difrakasi yang dihasilkan oleh masing-masing sampel memiliki nilai sudut $2 \theta$ yang berbeda-beda. 


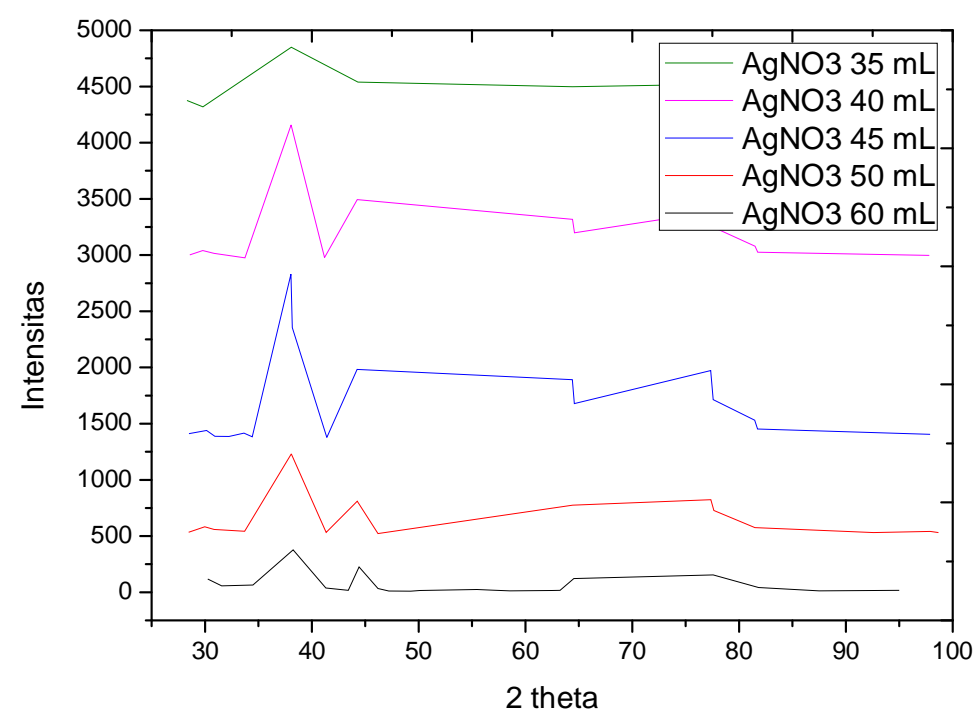

Gambar 1 Pola difraksi sinar x untuk kelima sampel

Pada Gambar 1 dapat dilihat bahwa puncak yang terbentuk untuk masing-masing sampel secara umum merupakan puncak-puncak Ag. Berdasarkan puncak-puncak tersebut dapat dihitung ukuran kristal dari masing-masing sampel. Ukuran kristal dari kelima sampel dapat dilihat pada Tabel 1. Berdasarkan tabel 1 terlihat bahwa ukuran kristal untuk kelima sampel cenderung semakin kecil seiring dengan berkurangnya variasi $\mathrm{AgNO}_{3}$ yang digunakan, kecuali untuk sampel 2. Hal ini dikarenakan pada sampel 2 kulit manggis yang digunakan berasal dari daerah yang berbeda dibandingkan dengan sampel yang lainnya. Perbedaan kondisi lingkungan tempat tumbuhnya tanaman dapat menyebabkan perbedaan jenis dan jumlah dari metabolit sekunder yang terkandung di dalamnya (Kardono, 2003).

Kondisi optimum yaitu ketika ukuran nanopartikel perak paling kecil didapatkan pada saat jumlah $\mathrm{AgNO}_{3} 35 \mathrm{~mL}$. Hal ini dikarenakan jumlah $\mathrm{AgNO}_{3}$ yang kecil akan menyebabkan partikel yang terbentuk semakin sedikit, sehingga akan sulit terjadi interaksi antar partikel yang dapat membentuk partikel baru dengan ukuran yang lebih besar. Berdasarkan indeks miller yang didapatkan untuk semua sampel, menunjukkan bahwa struktur kristal yang terbentuk untuk nanopartikel Ag adalah FCC (Face Centre Cubic).

Tabel 1 Perbandingan ukuran nanokristal Ag untuk setiap sampel

\begin{tabular}{ccc}
\hline Sampel & Variasi AgNO $_{\mathbf{3}}$ & Ukuran Kristal \\
\hline 1 & $60 \mathrm{~mL}$ & $126,55 \mathrm{~nm}$ \\
2 & $50 \mathrm{~mL}$ & $78,95 \mathrm{~nm}$ \\
3 & $45 \mathrm{~mL}$ & $103,48 \mathrm{~nm}$ \\
4 & $40 \mathrm{~mL}$ & $79,08 \mathrm{~nm}$ \\
5 & $35 \mathrm{~mL}$ & $32,29 \mathrm{~nm}$ \\
\hline
\end{tabular}

\subsection{Morfologi Permukaan}

Morfologi permukaan dari masig-masing sampel diperoleh dari hasil SEM dengan perbesaran 2.000 kali. Berdasarkan hasil karakterisasi SEM, bentuk morfologi dari masingmaisng sampel berbeda-beda seperti yang terlihat pada Gambar 2 . 


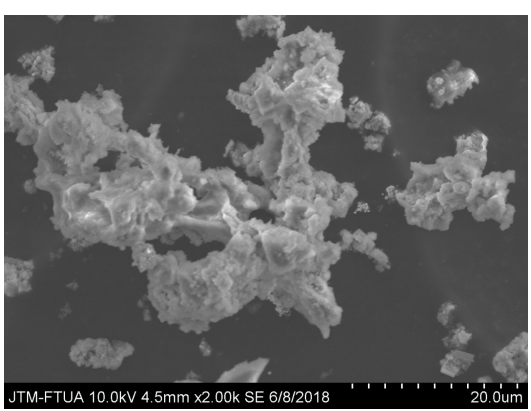

(a)

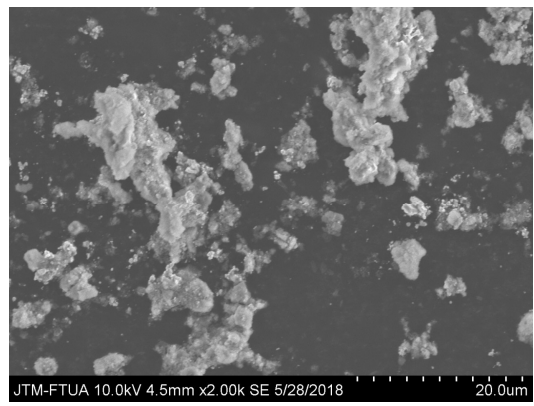

(c)

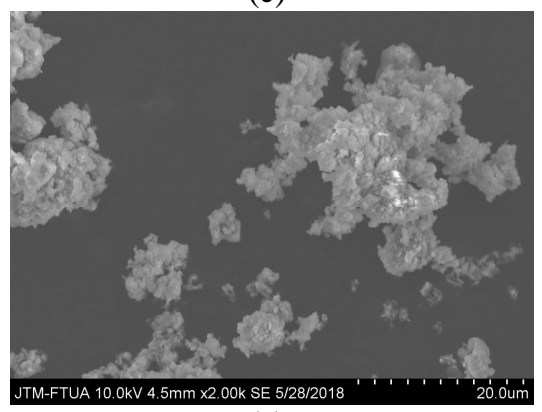

(e)

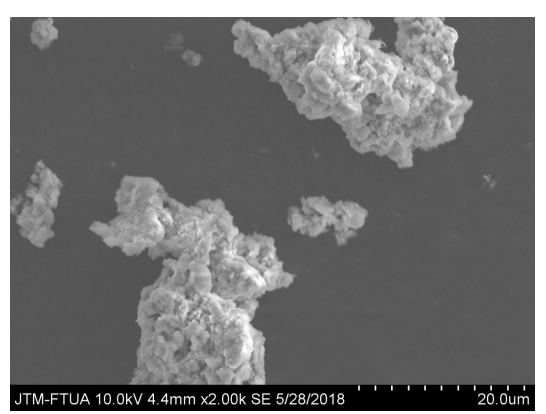

(b)

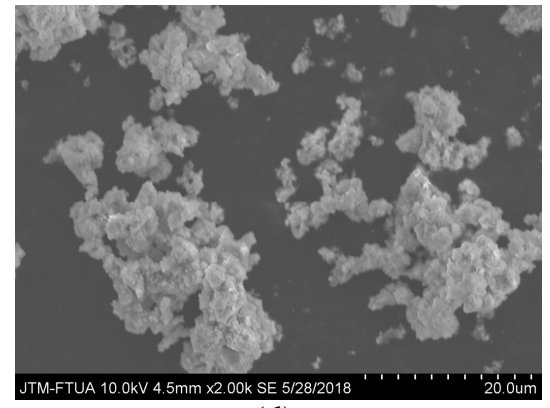

(d)

Gambar 2 Morfologi permukaan (a) Sampel 1 (b) sampel 2 (c) sampel 3 (d) Sampel 4 (e) Sampel 5

Gambar 2 menunjukan hasil SEM untuk 5 sampel. Morfologi permukaan partikel untuk kelima sampel rata-rata masih terdapat gumpalan. Hal ini kemungkinan disebabkan oleh sampel yang belum homogen ketika diaduk. Selain itu, sampel juga membentuk kelompok-kelompok (cluster).

\subsection{Gugus Fungsi dan Ikatan}

Analisis dengan menggunakan FTIR bertujuan untuk mengetahui bahwa telah terjadi ikatan antara senyawa aktif yang ada pada ekstrak kulit buah manggis dengan molekul $\mathrm{AgNO}_{3}$ sehingga menghasilkan nanopartikel perak. Hasil spektrum FTIR untuk masing-masing sampel terlihat pada Gambar 3.

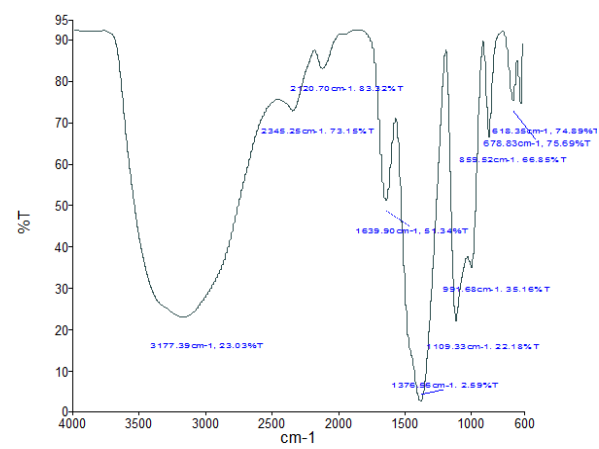

(a)

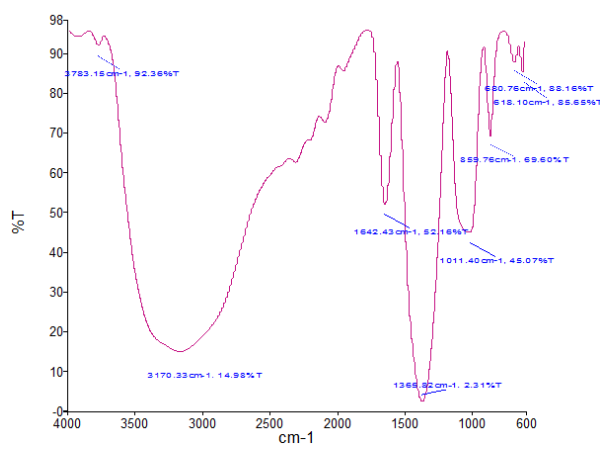

(b) 


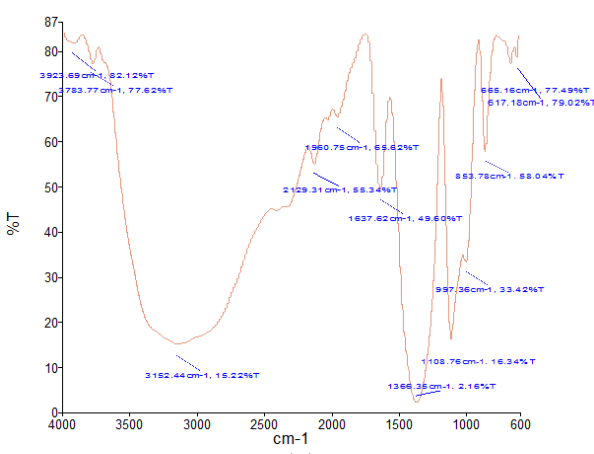

(c)

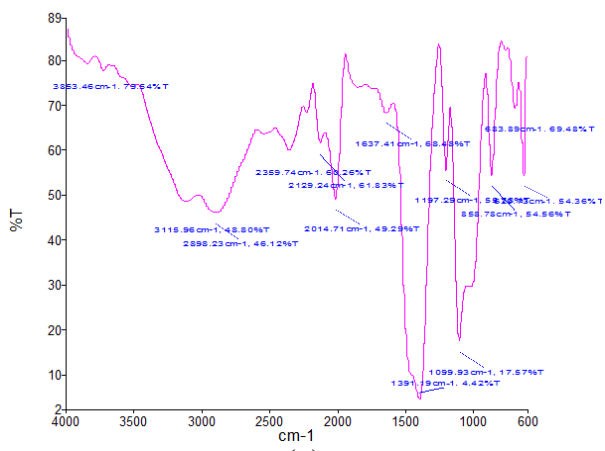

(e)

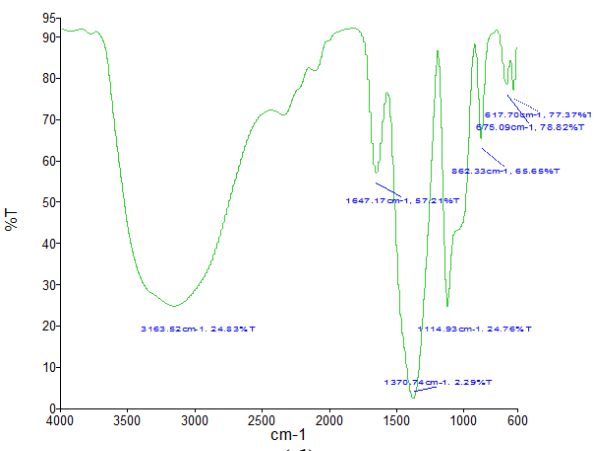

(d)

Gambar 3 Hasil spektrum FTIR untuk (a) sampel 1 (b) sampel 2 (c) sampel 3 (d) sampel 4 (e) sampel 5

Berdasarkan hasil spektrum FTIR untuk kelima sampel, didapatkan banyak peak pada bilangan gelombang yang berbeda-beda. Setiap sampel memiliki peak pada bilangan gelombang dengan rentang $3590-3650 \mathrm{~cm}^{-1}$ yang merupakan ikatan $\mathrm{O}-\mathrm{H}$ dengan tipe senyawa alkohol dan fenol. Selain itu, juga terdapat peak pada bilangan gelombang antara $2500-2700 \mathrm{~cm}^{-1}$ yang juga merupakan ikatan $\mathrm{O}-\mathrm{H}$ dengan tipe senyawa monomer asam karboksilat dan ikatan hidrogen asam karboksilat Gugus polar pada ikatan $\mathrm{O}-\mathrm{H}$ yang berasal dari ekstrak kulit buah manggis yang memiliki kemampuan yang baik untuk bereaksi dengan ion logam (seperti: ion perak). Menurut Gururnathan dkk (2009), ion hidroksida diperlukan untuk mempercepat proses reduksi ion $\mathrm{Ag}+$.

Selain itu, setiap sampel juga memiliki peak pada bilangan gelombang dengan rentang $3300-3500 \mathrm{~cm}^{-1}$ yang merupakan ikatan N-H dengan tipe senyawa amina dan amida. Protein yang terdapat pada ekstrak kulit buah manggis yang memiliki gugus amina berperan dalam proses reduksi ion $\mathrm{Ag}+$ menjadi nanopartikel Ag. Pada saat terjadinya proses reduksi terjadi penambahan elektron sehingga muatan dari ion Ag menjadi tidak bermuatan (Timberlake, 1997).

\section{KESIMPULAN}

Sintesis nanopartikel perak telah berhasil dilakukan dengan menggunakan kulit buah manggis. Berdasarkan hasil karakterisasi menggunakan XRD terdapat kecenderungan bahwa semakin kecil jumlah $\mathrm{AgNO}_{3}$ yang digunakan, semakin kecil ukuran nanokristal yang dihasilkan. Kondisi optimum dengan ukuran nanokristal perak paling kecil didapatkan pada jumlah $\mathrm{AgNO}_{3} 35 \mathrm{~mL}$ dengan ukuran diameter kristal 32,2908 nm. Nanopartikel perak yang dihasilkan memiliki struktur kristal kubik FCC (Face Centre Cubic). Berdasarkan hasil SEM dilihat bahwa morfologi nanopartikel masih terdapat gumpalan.

\section{DAFTAR PUSTAKA}

Abdullah, M., Pengantar Nanosains, (Cetakan Pertama, ITB, Bandung, 2009).

Astuti, Claudia, G., Noraida, and Ramadhani, M., Synthesis of $\mathrm{Fe}_{3} \mathrm{O}_{4}$ Nanoparticles from Ironstone Prepared by Polyethylene Glycol 4000, Makara J. Sci, 17, 58-62 (2013). 
Apriandanu, DOB, S. Wahyuni, S. Hadisaputro, dan Harjono, Sintesis Nanopaertikel Perak Menggunakan Metode Poliol dengan Agen Stabilisator Polivinilalkohol (PVA), FMIPA Universitas Negeri Semarang, Jurnal MIPA, 36, 157-168 (2013).

Gopinath, V., Mubarak Ali, D., Priyadarshini, S.,Priyadharsshini, N. M., Thajuddin, N., Velusamy, P. Biosynthesis of perak nanoparticles from Tribulus terrestris and its antimicrobial activity: a novel biological approach. Colloids and Surfaces Biointerfaces 96, 69-74 (2012).

Gururnathan, S., Kalimuthu ,K., Ramanathan, V., Venkataraman, D., Sureshbabu, RKP., Jeyaraj M, Nellaiah H, and Soo HE, Biosynthesis, purification, and characterization of silver nanoparticles using E. coli, Colloids and surface B: Biointerfaces, 74, 328-335 (2009).

Junaidi, A.B., Wahyudi, A., dan Umaningrum, A., Kajian Sintesis Nanopartikel Perak pada Komposit Kitosan dan Polietilena Glikol : Efek Jenis Agen Pereduksi Organik, Prosiding Seminar Nasional Kimia, 148-156 (2015).

Kardono LBS, Kajian Kandungan Kimia Mahkota Dewa (Phaleria marcocarpa), Jakarta, Pusat Penelitian dan Pengembangan Farmasi dan Obat Tradisional Badan Penelitian dan Pengembangan Kesehatan (2003).

Masakke, Y., Sulfikar, Muhaedah, R., Biosintesis Partikel-nano Perak Menggunakan Ekstrak Metanol Daun Manggis (Garcinia mangostana L.), Jurnal sainsmart, 4, 28-41 (2014).

Perdana, F.A., Mashuri., Triwikantoro., dan Darmanto., Sintesis Nanopartikel $\mathrm{Fe}_{3} \mathrm{O}_{4}$ dengan Template PEG-1000 dan Karakterisasi Sifat Magnetiknya . Jurnal Material dan Energi Indonesia, 1, 1-6 (2010)

Timberlake, B., and Bridle P., the anthocyanin. Di dalam J.B. Horborne (ed), The Flavanoid, Chapman and Hall, (London, 1997) Hal 215-230 